\title{
Linkages between responses to the available amenities and expressed environment-related health needs in international refugee camp, Oru-Ijebu, Nigeria
}

\author{
A. O. Afon ${ }^{1}$, M. A. Asani ${ }^{2}$, S. A. Adeyinka ${ }^{1}$, A. Z. Hasan ${ }^{3}$, \\ M. S. Jimah ${ }^{3}$, T. U. Ilogho ${ }^{3}$, T. G. Faborode ${ }^{1}$, G. B. Faniran ${ }^{1}$ \\ \& K. O. Popoola ${ }^{1}$ \\ ${ }^{1}$ Obafemi Awolowo University, Ile-Ife, Nigeria \\ ${ }^{2}$ Ladoke Akintola University of Techn ology, Ogbomoso, Nigeria \\ ${ }^{3}$ Auchi Polytechnic, Auchi, Nigeria
}

\begin{abstract}
This study investigated the relationship between the refugees' responses to the available amenities and the expressed health needs that are environment-related. Subjecting the data obtained from the refugees in Oru-Ijebu international refugee camp, Nigeria to analysis, a link between the adequacy level of existing environmental amenities and environment-unfriendly behaviour exhibited by the refugees, producing conditions that favour diseases was established. Similarly, a very high degree of relationship was found between the environment produced by refugees' responses and the expressed health needs of the refugees as revealed by the records of the diseases treated in the camp's health centre over a five year period. The study concluded that the need to provide adequate amenities and enforce environmental sanitation rules and regulations cannot be overemphasized. Furthermore, environmental education and enlightenment programs should be introduced in all the different phases of a camp's development.
\end{abstract}

Keywords: expressed health needs, refugee camp, environment-related health needs, environmental education, responses to available amenities. 


\section{Introduction}

The office of the United Nations High Commissioner for Refugees (UNHCR) was established in December 14, 1950 [1]. It was to protect and support refugees at the request of a government or the United Nations itself. It was also expected that UNHCR should assist in refugees' return or resettlement.

Under International Law, refugees are individuals who are:

outside their country of nationality or habitual residence; have a well founded fear of persecution of their race, religion, membership in a particular social group or political opinion, and are unable or unwilling to avail themselves of the protection of that country, or to return there, for fear of persecution [1].

In the 1950s, many nations in Africa suffered series of civil wars and ethnic strife. This generated a massive number of refugees at that time. It is on record that refugees in Africa increased from 560,000 in 1968 to 6,775,000 in 1992 [2]; although the number dropped to $2,748,400$ by the end of 2004 [2].

By the end of 2004, about 5000 or more refugees were found across such African countries as Sudan $(930,612)$, Burundi $(485,764)$ Democratic Republic of Congo $(462,203)$, Somalia $(389,272)$, Liberia $(335,467)$ and Angola $(228,838)$ [3].

Of importance to us in this study is the environmental health effects of the Liberian refugees in Nigeria. In order to receive the refugees from the Liberian civil war, the Federal Government of Nigeria established an agency - the National Commission for Refugees (NCFR) through Decree No. 52 of 1989 [4]. The agency was to work in collaboration with the UNHCR whose headquarters was in Geneva, the Switzerland. The NCFR was to provide a site for the stranded Liberian refugees in Apapa, Lagos- the former national capital city of Nigeria. This development gave birth to a refugee camp in Oru-Ijebu, Ogun State; the only state in Nigeria that shares boundary with Lagos.

The camp was formally opened on November 17, 1990. At the inception, the site was named Liberian Refugee Camp. This was because the camp only hosted refugees from Liberia. In 1997, due to internal strife in Sierra Leone, refugees were brought from the country. Thus, the camp was re-named Oru Refugee camp. Since this development, any person granted the status of a refugee by both the Federal Government of Nigeria and UNHCR was sent to the camp for habitation. As at the time of data collection for this study, there were 4917 refugees in the camp [5]. Table 1 below shows the distribution of the refugees according to their countries of origin. The highest proportion of the refugees in the camp $(85.4 \%)$ were Liberians.

The camp site was the former Muslim Teacher Training College, established in 1953 but eventually closed down along with others in 1982. This was when the minimum qualification of teachers in primary school was raised to National Certificate of Education. Therefore, until 1990 when the school site was turned to a refugee camp, it was an abandoned site.

The camp inherited from the Muslim Teachers College six blocks of hostels, an administrative block, a block of twelve classrooms, three blocks of residential 
Table 1: $\quad$ Refugees and countries of origin.

\begin{tabular}{|c|c|c|}
\hline Nationality & Number of refugees & $\%$ \\
\hline Liberian & 4198 & 85.4 \\
\hline Sierra Leone & 640 & 13.02 \\
\hline Democratic republic of Congo & 38 & 0.77 \\
\hline Sudan & 20 & 0.41 \\
\hline Rwanda & 10 & 0.20 \\
\hline Ivory coast & 6 & 0.12 \\
\hline Cameroon & 2 & 0.04 \\
\hline Burundi & 1 & 0.02 \\
\hline Chad & 1 & 0.02 \\
\hline Ghana & 1 & 0.02 \\
\hline Total & 4917 & 100 \\
\hline
\end{tabular}

Source: [5].

staff quarters and a mosque. Upon becoming a refugee camp, the administrative block remained as the offices of the camp management staff while the three blocks of staff quarters became their residences. All the classrooms in addition to the six blocks of students' hostels became the residential accommodation for the refugees. The refugee camp occupied a land area of 4.2 hectares [5].

It is widely acknowledged that an estimated $80 \%$ of refugees are women and children [2,6]. These women often carry the heaviest burden of survival for themselves and their families. It is also noted that children and youth constituted approximately $50 \%$ of all refugees world wide [2]. They are usually the deliberate targets of abuse, military recruitment and abduction [2]. It is reported that more than 43 million children living in conflict-affected areas do not have a chance to go to school [2].

Women and adolescent girls in refugee settings are especially vulnerable to exploitation, rape, abuse and other forms of gender-based violence [2]. These are in addition to the general condition of risks for diseases and lack of accessibility to adequate health care, poor level of environmental amenity provisions (like water and sanitation), decent housing and general poor environmental conditions. Meeting the above and other needs in refugee camp becomes problematic for a number of factors. As observed by UNHCR [6] the complexity of problems to be managed vary from the different phases of assistance to refugees and from one physical and locational settings to another. The 'emergency relief' phase for example is the most critical period of meeting the needs of the refugees. This is because of the unpredictability of the number of people involved, the direction in which people might flee for safety or what the resulting impact on local settlements and the environment is likely to be [6]. The 'care and maintenance' also known as 'monitoring' phase according to Bjorgo [7] is when the refugee population in a camp becomes relatively stable. Main activities during this stage should be proactive, taking a long-term approach of managing both the natural and man-made resources on the camp for the benefit of the people. The third phase is the 'durable solutions' or rehabilitation [6]. 
Whatever the level of adequacy of environmental amenities provided in a camp would attract responses from the refugees. This is also true of all human settlements. Ezzati et al. [8] noted that behaviour producing hazards could be natural or responses to inadequate environmental amenities or both. For example, whether toilet facility is provided or not, it is inevitable, people must go to toilet. Similarly, whether waste disposal facility is available or not, it is inevitable to generate and dispose waste. Furthermore, waste water must be produced and disposed. For instance, Trevino and Farnandez [9] commented that the presence of raw sewage in the street of Nogales is traced to 'responses to housing deficit and inadequate availability of sewage disposal system. Sadalla et al. [10] also arrived at similar conclusion in their study of Arizona - Sonora where they noted that residential behaviour including trash burning, the energy utilized in cooking, methods of bathing and construction of toilet facilities. Were all responses to adequacy level of amenities.

Refugee camps can be likened to low income urban neighborhoods which suffers poorer basic municipal services. The responses to these inadequacies usually lead to human changes of environment that meet conditions that favour diseases, disturb and release-noxious levels of previously bound chemicals. Through the changes effected on the environment, all humans are exposed to environmental factors through the air breath, the water intake, contact with different substances and preparations [11]. Key health threats that are common where human responses to environmental amenity inadequacies favour diseases may include diarrhea, typhoid fever, cholera, acute respiratory infections such as pneumonia, tuberculosis, skin rashes among others.

One major method of recognizing the health effects of residents' responses to environmental amenities provided is through the records of diseases treated in the neigbourhood health centres. This is referred to as the expressed health needs. The yearly summary of the cases handled in health centre serving a refugee camp provides a good guide to determining the health needs that are related to environmental factors. This is because the patterns and prevalence of self-reported health problems reflect both underlying diseases and consequently health needs [12]. This observation is true for both the normal residential quarters of citizens and refugees.

The purpose of this study is to examine in the first place the level of environmental amenities made available for refugees consumption in a camp located in Ogun State, Nigeria. Second, evaluation is made of refugees' responses to the level of adequacy of the available amenities. Such responses will have environmental consequences which may develop into environmentrelated health problems. The complexity of environmental consequences and the associated health problems will be known through the analysis of the health records of the diseases treated in the refugees' health centre. This represents the health needs of the refugees.

This study is of significant importance for a number of reasons. In the first place, there is every evidence that man would continue to be displaced either through natural and man-made means. Hence, the need to plan and design refugee camp by professionals like architects, town planners and other social 
workers will remain with us. Second, the international body (UNHCR) and the local ones will be able to recognize that inadequate provision of environmental amenities in a refugee camp may not be as dangerous as the responses that people will put up to cope with such inadequacies. And that, where responses to the lack of amenities promote environment that supports health risk, the health needs of the refugees will be environment-related. This study will therefore sensitize policy makers to take it as responsibility to provide minimum level of amenities that will promote good health condition of refugees.

\section{Methodology}

The study utilized two sets of data. The first was the data collected from the refugees through questionnaire administration. To administer the questionnaire, the refugee camp was stratified into the existing 12 residential blocks. Twenty percent (one out of every five) of the rooms was systematically selected for survey. Presented in Table 2 are the names of blocks, the number of rooms in each block and the number of rooms sampled. A total of 71 refugees were sampled. Information obtained included socio-economic background, their knowledge of the available amenities and responses to the adequacy level of environmental amenities.

Table 2: $\quad$ Rooms selected for survey in each residential block on camp.

\begin{tabular}{|c|c|c|}
\hline Block name & Total no of rooms & No of rooms sampled \\
\hline Diplomatic & 35 & 7 \\
\hline Nairobi & 25 & 5 \\
\hline JFK & 25 & 5 \\
\hline IBB & 20 & 4 \\
\hline King villa & 21 & 4 \\
\hline Pastoral & 21 & 3 \\
\hline Block J & 16 & 5 \\
\hline Cabral & 25 & 4 \\
\hline Western Australia & 20 & 3 \\
\hline Nooh Ark & 16 & 3 \\
\hline Later day saints & 16 & 24 \\
\hline 60 housing units & 120 & 71 \\
\hline Total & 360 & 4 \\
\hline
\end{tabular}

Source: Filed survey, 2006.

The second set of data was collected from the health centre located on the camp. A range of information on the health statistics of all diseases treated were solicited and environment-related ones; that is, those related to sub-optional environment that could have resulted from responses to inadequate amenities were isolated. The information was obtained over a five year period of 2001 to 2005 . 


\section{Research findings}

First to be examined in this section is the environmental amenities made available in the camp for refugees. Included in these amenities are housing and the associated facilities like toilets, water supply, solid and waste water management. All tables under this section are from the authors' survey of 2006.

Residential accommodation is one of the major problems in refugee camps all over the world. The refugee camp under investigation is not an exemption. With increased population from time to time, effectively housing the refugees became a serious problem. To supplement existing structures met on ground, the UNHCR in conjunction with the Ijebu North Local Government constructed sixty housing units. Each housing unit is made of two rooms. Investigation confirmed that the refugees contributed manual labour in the construction process. Despite the existing hostels used by students of the defunct Muslim Teachers' College and the sixty housing units constructed, some refugees were housed in classrooms and tarpaulin cover. The research further revealed that most rooms were over crowded. Refugees residing in classrooms and tents had no access to toilet facilities.

Refugees responded to the absence of adequate housing and associated facilities, in many different ways. For example, inadequate housing space has led to overcrowding. It was established that $48.8 \%$ of the refugees had occupancy ration of between 4 and 7 people sleeping in a room and the $29.6 \%$ of the refugees had over 7 persons per room. Recall that overcrowding can lead to the outbreak and spread of diseases like asthma, cough and catarrh.

Accessibility to potable water by the refugees was poor. It was evident that the site had long ago been connected to public water mains. However, this source of water was no more functional. Similarly, there were eight spots where boreholes were sunk. As of August, 2006, only 50\% of these were functioning and indeed $78 \%$ of the camp dwellers claimed that water from the boreholes was not potable. Over a quarter $(26.6 \%)$ of the refugees made use of water from streams located within and in close proximity to the camp. Rain harvest accounted for $7.5 \%$ of water sources in the camp.

Similarly, one of the most popular means of responding to lack of toilet and /or poor conditions of toilet facility is the use of nearby bush. Over a third of the refugees sampled $(41.3 \%)$ were in the habit of using the bushes around as toilet. This method of using bushes to serve as toilet is very risky. This is because rain water run-off would wash human excreta into rivers and streams that are used for domestic purposes which may include drinking. It was therefore noted that a major source of pollution is through poor human fecal disposal practice.

Refugees' waste disposal practices in the absence of environment-friendly and sustainable means also varied. It is established that refugees used a combination of these methods. Three important methods of waste disposal were identified in the camp. The most important method of waste disposal was dumping on a designated spot. It accounted for $58.1 \%$ of the responses. Next in importance was burning. This is an act that was commonly in practice during the dry season. It accounted for $29.7 \%$ of the methods. Disposing waste 
indiscriminately (on any available space) accounted for $12.2 \%$ of the methods. The environmental consequences of these methods are many. Open dumping makes it possible for diseases carrying vectors (flies, cockroaches, rodents, birds) to have access to waste. Through these vectors, foods both at home and on farms are contaminated. Burning waste generates noxious gasses that are emitted into the air and inhaled not only by those who practiced this method. Disposing waste indiscriminately has the possibility of causing wounds on residents through sharp objects disposed. This is in addition to the problem associated with dumping of waste on designated open space.

Other general problems identified that are related to refugees' responses to inadequate environmental amenities include those from poor management of waste water from kitchens, bathrooms and toilets. Pits and septic tanks to receive waste water were absent. In essence, such waste water are good breeding points for mosquitoes and also generates unsightly condition and bad odour.

From the above analyses, conclusion can be drawn that the level of environmental amenities provided for the refugees were not adequate in OruIjebu camp. The consequences of the inadequacies resulted into refugees' responses that were not environment-friendly.

Before the examination of the relationship between the environmental consequences of refugees' responses to inadequacies of facilities and the expressed health needs, refugees were instructed to identify the different environmental problems perceived to be present on camp. Summarized in Table 3 are the different environmental problems identified. The most prominent problem was the prevalence of disease vectors. These vectors include rodents, cockroaches, mosquitoes and flies. The problem accounted for $16.5 \%$ of all; and $88.7 \%$ of the refugees identified it. Others with significant dimensions include poor housing conditions $(16.0 \%)$, poor sanitation conditions $(13.9 \%)$, poor water supply $(12.9 \%)$ and over crowding $(9.7 \%)$.

To establish the relationship between the environmental problems emanating from the consequences of refugees response to inadequate facilities and their expressed health needs, records of diseases treated in the health centre on the camp were obtained over a five year period of 2001 to 2005. Presented in Table 4 are the findings of environment-related ailments treated arranged in the descending order of magnitude. Malaria, an ailment mainly caused and transmitted by the bite received by human from a type of mosquitoes accounted for $71.2 \%$ of all diseases treated in the camp's health centre. Next in magnitude of occurrence was dysentery and diarrhea (11.9\%); an ailment that is mainly caused by the intake of untreated water. Other diseases traceable to intake of untreated water include typhoid fever $(0.7 \%)$ and cholera $(0.1 \%)$. These three diseases combined represented $12.8 \%$ of all the diseases treated. Cough, which accounted for $5.3 \%$ can be traced to pollution from burning of waste and can be spread through overcrowding in housing condition. Running nose, representing $2.8 \%$ of the ailments treated can be traced to pollution from using firewood as cooking fuel.

From this simple analysis, it is evident that relationship exised between the health needs expressed by refugees and the environmental problems identified 
Table 3: $\quad$ Environmental problems identified by refugees on the camp.

\begin{tabular}{|c|c|c|}
\hline Environmental problems & $\begin{array}{l}\% \text { of the } 71 \\
\text { refugee sampled }\end{array}$ & $\begin{array}{l}\% \text { of the } \\
\text { problem }\end{array}$ \\
\hline Poor sanitation & 74.6 & 13.9 \\
\hline Poor housing condition & 85.9 & 16.0 \\
\hline Poor water supply & 69.0 & 12.9 \\
\hline Overcrowding & 52.1 & 9.7 \\
\hline $\begin{array}{l}\text { Pollution from fire wood } \\
\text { used as cooking fuel }\end{array}$ & 36.6 & 6.8 \\
\hline $\begin{array}{l}\text { Prevalence of disease } \\
\text { vectors }\end{array}$ & 88.7 & 16.5 \\
\hline $\begin{array}{l}\text { Pollution from burnt } \\
\text { solid waste }\end{array}$ & 29.6 & 5.5 \\
\hline $\begin{array}{l}\text { Pollution from human } \\
\text { fecal }\end{array}$ & 47.9 & 8.9 \\
\hline $\begin{array}{l}\text { Pollution from bad } \\
\text { management of waste } \\
\text { water }\end{array}$ & 26.8 & 5.0 \\
\hline $\begin{array}{l}\text { Pollution from open } \\
\text { waste dump }\end{array}$ & 25.4 & 4.7 \\
\hline $\mathrm{N}$ & & 381 \\
\hline
\end{tabular}

Table 4: Records of environment-related diseases treated in the health centre on the camp.

\begin{tabular}{|c|c|c|c|c|c|c|c|}
\hline \multirow{2}{*}{$\begin{array}{c}\text { Disease } \\
\text { treated }\end{array}$} & \multicolumn{5}{|c|}{ Year } & $\begin{array}{c}\text { Total } \\
\text { per } \\
\text { disease }\end{array}$ & $\begin{array}{c}\% \text { to } \\
\text { grand } \\
\text { total }\end{array}$ \\
\hline Malaria & 2143 & 2213 & 2194 & 1701 & 1906 & 10157 & 71.2 \\
\hline $\begin{array}{c}\text { Diarrhea \& } \\
\text { Dysentery }\end{array}$ & 352 & 439 & 330 & 310 & 273 & 1704 & 11.9 \\
\hline Cough & 93 & 152 & 170 & 183 & 160 & 758 & 5.3 \\
\hline $\begin{array}{c}\text { Abdominal } \\
\text { Pain }\end{array}$ & 80 & 123 & 114 & 130 & 77 & 524 & 3.7 \\
\hline Running nose & 63 & 77 & 91 & 87 & 79 & 397 & 2.8 \\
\hline Chicken pox & 38 & 63 & 55 & 51 & 40 & 247 & 1.7 \\
\hline Skin (rashes) & 16 & 41 & 51 & 48 & 45 & 201 & 1.4 \\
\hline Common cold & 13 & 22 & 20 & 22 & 38 & 115 & 0.9 \\
\hline Typhoid fever & 13 & 16 & 24 & 21 & 19 & 93 & 0.7 \\
\hline Sore Throat & 03 & 09 & 12 & 04 & 06 & 34 & 0.2 \\
\hline Cholera & - & - & 16 & 02 & 01 & 19 & 0.1 \\
\hline Asthma & 03 & - & 02 & 03 & 08 & 16 & 0.1 \\
\hline Total & 2817 & 3155 & 3079 & 2562 & 2652 & 14265 & 100.0 \\
\hline \% & $19.7 \%$ & 22.1 & 21.6 & 18.0 & 18.6 & & \\
\hline
\end{tabular}


which are the consequences of the different responses of the refugees to inadequate supply of amenities on the camp.

\section{Conclusion}

This study has significant implications for the refuge camps to be developed in the future and monitoring of existing ones. Although the planning and development of new refugee camps, is usually an emergency activity, it behoves both the UNHCR and the government of the country hosting the camp to be aware of the responsibilities on their shoulders. These include the provision of amenities and services. Indeed, the different professionals taken part in the planning and design of refugee camps are not left out in the fulfillment of these great responsibilities. Services like water and housing, and the associated facilities (toilet, waste water and solid waste management services) should be provided to prevent responses from the refugees that will produce negative environmental consequences. It is suggested that the location of refugee camp should not be completely segregated from an existing urban centre. This is to reduce initial costs of providing amenities that are usually very high. Services could be extended from existing cities to the camp. For example, if the distance between a refugee camp and an existing city is reasonable, solid waste collection service available in the city could be extended to the refugee camp.

It is also imperative that the camp management should embark on environmental education and enlightenment campaign to the refugees. Educating refugees on the basic rule of hygiene will go a long way to producing environment-friendly attitude among them. Part of the enlightenment campaign can be on how to avoid the outbreak of communicable diseases especially through water intake, when the sources of water available are in suspect to be dangerous to human healthy living.

In another dimension, the camp management may have to make and enforce environmental sanitation laws. This will prevent refugees from embarking on attitudes producing negative environmental consequences. This is important as it may be that not all responses are due to inadequate provision of environmental amenities; but due to ignorance and negligence.

As it is difficult if not impossible to prevent the development of refugee camps, it is essential that those involved in the design, planning and management to be ready to improve the environmental quality of the camp. This will prevent the spending of higher portion of the camp's budget on the curing the refugees of environment-related diseases and by extension the host community.

\section{References}

[1] Wikipedia, the free encyclopedia, Refugee. http://en.wikipedia.org/ wiki/refugee assessed 17th April, 2009.

[2] Encyclopedia Britannica, Refugees. http://www.britanica.com/eb/ article? tocld $=9063088$ assessed $14^{\text {th }}$ April, 2009. 
[3] United Nations High Commissioner for Refugees (UNHCR), Global Refugee Trends. http:///www.unhcr.ch/cgi-bin/texis/vtx/statistics/opendox assessed 17th April, 2009.

[4] Federal Republic of Nigeria, Establishment of the National Commission for Refugees (NCFR). Decree No. 52; Government Press, Lagos, 1989.

[5] National Commission for Refugee (NCFR), Handbook on Refugee Camp Oru-Ijebu, Nigeria. Federal Government Press, Lagos, 2002.

[6] United Nation High Commissioner for Refugees (UNHCR), Help us give them shelter: we can't do it alone. http://www.unhcr.org/protect/ PROTECTION/360366F44.htm assessed 20th April, 2009.

[7] Bjorgo, E., Refugee Camp mapping using very high spatial resolution satellite sensor images. Geocarto International, 15(2), pp 8-15, June, 2000.

[8] Ezzati, M., Utzinger, J., Caincross, S., Cohen, A. J. and Sugar, B. H., Environmental risks in the developing world: exposure indicators for evaluating intervention programs and policies. Journal of Epidemiology, and Community Health, 59, pp 5-22, 2005.

[9] Travino, M., and Fernandez, A., The Maquiladora industry: adverse environmental impact and proposed solutions. Journal of Borderland Studies, 7, pp 53-72, 1992.

[10] Sadala, E., Swanson, T. and Velasco, J., Residential behaviour and environmental hazards in Arizona - Zonora Colonia. Project Report Number EH 98 - 2, Department of Environmental Quality Boarder Team, Arizona State University, 1999.

[11] Danish Environmental Protection Agency (DEPA), Environmental factor and health: the Danish experience. http://www.mst.dk/ assessed $11^{\text {th }}$ June, 2006.

[12] Reigneveld, S. A. and Stronks, K., The validity of self-reported use of health care across socio-economic strata: a comparison of survey and registration data. International Journal of Epidemiology, 30, pp. 1407 1414, 2001. 